\title{
Pengaruh Model Pembelajaran Contextual Teaching and Learning terhadap Hasil Belajar IPA
}

\author{
Gede Putu Widyaiswara ${ }^{1 *}$, Desak Putu Parmiti2 ${ }^{2}$ I Made Suarjana ${ }^{3}$
}

123Jurusan Pendidikan Guru Sekolah Dasar, Universitas Pendidikan Ganesha, Indonesia

\begin{tabular}{l} 
A R T I C L E I N F O \\
\hline Article history: \\
Received 18 August 2019 \\
Received in revised form \\
19 September 2019 \\
Accepted 25 October 2019 \\
Available online 30 \\
November 2019 \\
\hline Kata Kunci: \\
CTL, hasil belajar, IPA \\
Keywords: \\
CTL, learning outcomes, \\
science
\end{tabular}

\section{ARTICLEINFO}

Received 18 August 2019

Accepted 25 October 2019 Available online 30

Kata Kunci:

TL, hasil belajar, IPA

science

\begin{abstract}
A B S T R A K
Penelitian ini bertujuan untuk mengetahui adanya perbedaan hasil belajar IPA antara kelompok siswa yang dibelajarkan dengan menggunakan model pembelajaran Contextual Teaching and Learning dan kelompok siswa yang dibelajarkan dengan menggunakan model pembelajaran konvensional pada siswa kelas IV SD Gugus III Kecamatan Busungbiu Tahun Pelajaran 2018/2019. Penelitian ini merupakan penelitian eksperimen semu dengan rancangan penelitian adalah Non Equivalent Control Grup Design. Populasi penelitian ini adalah kelas V SD Gugus III Kecamatan Busungbiu Tahun Pelajaran 2018/2019. Sampel ditentukan random sampling diperoleh SDN 1 Pelapuan sebagai kelompok eksperimen yang berjumlah 18 orang dan SDN 3 Umejero sebagai kelompok kontrol yang berjumlah 19 orang. Data yang dikumpulkan adalah hasil belajar IPA meliputi aspek kognitif yang diperoleh dari tes hasil belajar. Data yang diperoleh dianalisis menggunakan analisis statistik inferensial (uji-t polled varians). berdasarkan hasil analisis data, diperoleh $t_{\text {hitung }}$ sebesar 5,28 lebih besar dari $t_{\text {tabel }} 2,042$ dengan taraf signifikansi $5 \%$ dan $d b=35$. Dilihat dari hasil perhitungan rata-rata hasil belajar IPA kelompok siswa yang
\end{abstract} dibelajarkan dengan model pembelajaran Contextual Teaching and Learning adalah 19,39 lebih besar dari rata-rata hasil belajar IPA kelompok siswa yang dibelajarkan dengan model pembelajaran konvensional yaitu 15,74. Jadi dapat disimpulkan bahwa model pembelajaran Contextual Teaching and Learning berpengaruh terhadap hasil belajar IPA siswa kelas V SD Gugus III Kecamatan Busungbiu Tahun Pelajaran 2018/2019.

\section{A B S T R A C T}

This study aims to determine the differences in science learning outcomes between groups of students who are taught using the Contextual Teaching and Learning learning model and groups of students who are taught using conventional learning models in class V SD Group III Busungbiu District 2018/2019 Academic Year. This research is a quasi-experimental study with a research design that is a Non Equivalent Control Group Design. The population of this research is class V SD Group III Busungbiu Subdistrict 2018/2019 Academic Year. Random sampling was determined by SDN 1 Pelapuan as an experimental group of 18 people and SDN 3 Umejero as a control group of 19 people. The data collected is the learning outcomes of science covering cognitive aspects obtained from learning outcomes tests. The data obtained were analyzed using inferential statistical analysis (polled variance t-test). based on the results of data analysis, obtained a tcount of 5.28 greater than ttable 2.042 with a significance level of $5 \%$ and $\mathrm{db}=35$. Judging from the results of the calculation of the average science learning outcomes of the students taught with the learning model Contextual Teaching and Learning is 19, 39 greater than the average science learning outcomes of the student group that was taught by conventional learning models, namely 15.74 . So it can be concluded that the learning model of Contextual Teaching and Learning has an effect on the science learning outcomes of fourth grade students of SD Cluster III Busungbiu Subdistrict 2018/2019 Academic Year.

Copyright @ Universitas Pendidikan Ganesha. All rights reserved.

\footnotetext{
${ }^{1}$ Corresponding author.

E-mail addresses: putuwidyaiswara1@gmail.com (Gede Putu Widyaiswara)
} 


\section{Pendahuluan}

Pendidikan merupakan suatu proses yang berlangsung secara berkelanjutan yang dapat membangkitkan keaktifan dan potensi siswa yang dilakukan secara sadar. Menurut Hamalik (2012:3) menjelaskan bahwa"pendidikan adalah suatu proses dalam rangka mempengaruhi peserta didik supaya mampu menyesuaikan diri sebaik mungkin dengan lingkungannya, dan dengan demikian akan menimbulkan perubahan dalam dirinya yang memungkinkannya untuk berfungsi secara adekwat dalam kehidupan masyarakat". Menurut Kasmawati (2017) Pendidikan merupakan salah satu faktor terpenting dalam menjalani hidup bermasyarakat. Sebab tanpa pendidikan, manusia tidak akan pernah mengubah strata sosialnya untuk menjadi lebih baik. Masalah terbesar dalam dunia pendidikan saat ini adalah masalah lemahnya proses pembelajaran. Dalam proses pembelajaran, anak kurang didorong untuk mengembangkan kemampuan berpikirnya, dan menjadikan sebuah pelajaran tersebut menjadi bermakna. Proses pembelajaran di dalam kelas hanya diarahkan kepada kemampuan anak untuk menghafal informasi. Otak anak dipaksa untuk mengingat dan menimbun berbagai informasi tanpa dituntut untuk memahami informasi yang diingatnya itu untuk menghubungkannya dalam kehidupan sehari-hari. Akibatnya, ketika anak didik kita lulus dari sekolah, mereka pintar secara teoretis, akan tetapi mereka miskin aplikasi.

Tujuan pendidikan menurut Undang-Undang No 20 tahun 2003 tentang Sistem Pendidikan Nasional, Pasal 3 adalah Mengembangkan potensi peserta didik agar menjadi manusia yang beriman dan bertakwa kepada Tuhan Yang Maha Esa, berhaklak mulia, sehat berilmu, cakap, kreatif, mandiri, dan menjadi warga negara yang demokratis serta bertangung jawab. Jadi pendidikan merupakan suatu aspek kehidupan yang sangat mendasar sebagai pembangunan bangsa. Pendidikan sekolah dasar merupakan jenjang pendidikan yang paling mendasar dan menjadi pondasi dalam mengembangkan aspek pengetahuan yang dimiliki siswa untuk memperoleh pengetahuan melalui proses pembelajaran.

Kurikulum merupakan syarat mutlak bagi pelaksanaan pendidikan di sekolah. Setiap pelaksanaan pendidikan diarahkan pada sebuah pencapaian-pencapaian tujuan yang telah ditetapkan. Menurut Lasmawan (2013:4)menyatakan bahwa "kurikulum dimaknai sebagai pengalaman belajar yang direncanakan sebagai dasar dan acuan dalam merencanakan, melaksanakan, mengevaluasi dan mengembangkan serta pelaksanaan dari kurikulum tersebut untuk mampu mentransformasi materi pendidikan menjadi pengalaman belajar bagi peserta didik". Kurikulum terdiri dari kumpulan mata pelajaran diantaranya IPA, IPS, Bahasa Indonesia, danlain sebagainya.

IPA merupakan salah satu mata pelajaran yang dianggap sulit disekolah dasar. Menurut Susanto (2013:167) menjelaskan bahwa"sains atau IPA adalah usaha manusia dalam memahami alam semesta melalui pengamatan yang tepat pada sasaran, serta menggunakan prosedur, dan dijelaskan dengan penalaran sehingga mendapatkan suatu kesimpulan". Jadi proses pembelajaran IPA sangat penting diterapkan untuk menambah pengetahuan siswa di sekolah dasar dan harus dilaksanakans esuai dengan strategi yang tepat agar siswa mudah memahaminya. Karera Pembelajaran IPA di sekolah dasar melibatkan anak-anak, maka proses pembelajaran harus dilaksanakan semenarik mungkin untuk memancing keaktifan serta minat belajar siswa dan guru juga harus tetap membimbing siswa untuk tetap disiplin. Menurut Sumiyadi (2015) Penguasaan IPA melalui pembelajaran secara teoritis sangat ditentukan oleh kemampuan dan kreatifitas siswa dalam menguasai keterampilan proses sains. Siswa yang mempunyai keterampilan proses bagus maka prestasi akademiknya juga bagus. Menurut Sulthon (2016) Pembelajaran IPA tidak bisa dengan cara menghafal atau pasif mendengarkan guru menjelaskan konsep namun siswa sendiri yang harus melakukan pembelajaran melalui percobaan, pengamatan maupun bereksperimen secara aktif yang akhirnya akan terbentuk kreativitas dan kesadaran untuk menjaga dan memperbaiki gejala-gejala alam yang terjadi untuk selanjutnya membentuk sikap ilmiah yang pada gilirannya akan aktif untuk menjaga kestabilan alam ini secara baik dan lestari. Menurut Handini (2016) Tercapainya tujuan pembelajaran IPA, diharapkan guru mampu mengajarkan pembelajaran IPA dengan baik dan benar agar peserta didik mudah memahami isi pembelajaran IPA. Pada saat mengajar guru haruslah kreatif dan bervariatif dalam hal memilih dan memilah metode, model, pendekatan, dan pengelolaan kelas. Hal itu akan mempermudah peserta didik untuk mencerna materi yang disampaikan oleh guru. Salah satu cara untuk melakukan sesuatu yang berbeda di dalam mengajar adalah dengan menggunakan model pembelajaran. Menurut Suriyani (2017) Pembelajaran IPA di sekolah diharapkan agar siswa mempunyai keterampilan berpikir kritis dan memecahkan masalah. Sebab, keterampilan berpikir kritis bukanlah pembawaan manusia sejak lahir namun bisa ditumbuh kembangkan. Dalam hal ini, guru memegang peranan penting dalam usaha pengembangan keterampilan berpikir kritis khususnya pada mata pelajaran sistem pencernaan manusia, agar siswa dapat memiliki pengalaman bagaimana menemukan satu konsep. 
Mata pelajaran IPA di sekolah dasar dianggap susah karena kajian teorinya yang luas sehingga di sekolah dasar banyak masalah-masalah yang ditemui oleh guru dan siswa dalam proses pembelajaran IPA. Seperti masalah-masalah yang ditemukan padasiswakelas V SD Gugus III Kecamatan Busungbiu Kabupaten Buleleng, dari hasil observasi yang dilakukan dengan guru-guru kelas IV yang ada di masingmasing sekolah ditemukan beberapa masalah yaitu, (1) kurangnya pemahaman siswa mengenai konsep pembelajaran IPA, (2) penggunaan model pembelajaran yang tidak relevan,(3) siswa masih kurang aktif dalam mengikuti proses pembelajaran, (4) proses pembelajaran masih berpusat pada guru, dan (5) nilai rata-rata hasil belajar IPA siswa masih tergolong rendah.

Tabel 1. Rata-rata Hasil Belajar IPA Siswa Kelas IV SD Gugus III Kecamatan Busungbiu

\begin{tabular}{ccccccc}
\hline No & Nama Sekolah & KKM & $\begin{array}{c}\text { Jumlah } \\
\text { Siswa }\end{array}$ & $\begin{array}{c}\text { Jumlah siswa di } \\
\text { bawah KKM }\end{array}$ & $\begin{array}{c}\text { Jumlah siswa } \\
\text { di atas } \\
\text { KKM }\end{array}$ & $\begin{array}{c}\text { Nilai Rata- } \\
\text { rata Kelas }\end{array}$ \\
\hline 1. & SDN 1 Pelapuan & 70 & 18 & 13 & 5 & 68,94 \\
2. & SDN 2 Pelapuan & 68 & 13 & 10 & 3 & 67,46 \\
3. & SDN 1 Umejero & 70 & 20 & 7 & 13 & 67.5 \\
4. & SDN 3 Umejero & 68 & 19 & 8 & 11 & 67,36 \\
\hline \multicolumn{2}{r}{} & Jumlah & $\mathbf{7 0}$ & $\mathbf{3 8}$ & $\mathbf{3 2}$ \\
\hline
\end{tabular}

Tabel 1 menunjukkan bahwa nilai rata-rata hasil belajar IPA siswa kelas V SD Gugus III Kecamatan Busungbiu berada dalam kategori rendah. Untuk mengatasi hasil belajar IPA yang rendah maka perlu adanya penyempurnaan dalam proses pembelajaran, seperti pada pemilihan model pembelajaran inovatif yang diterapkan oleh guru harus sesuai dengan materi pelajaran yang akan disampaikan. Hal itu sangat berpengaruh terhadap keaktifan belajar siswa.

Dari setiap masalah-masalah yang ditemukan tentunya pasti ada solusi yang bisa digunakan dalam memecahkan atau meringankan masalah tersebut. Untuk mengatasi masalah yang telah ditemukan di Gugus III Kecamatan Busungbiu maka di temukan solusi yaitu dengan menerapkan model pembelajaran Contextual Teaching and Learning merupakan suatu proses pembelajaran yang bertujuan untuk membelajarkan peserta didik dalam memahami suatu bahan ajar atau materi secara bermakna yang dikaitkan dengan konteks kehidupan nyata, baik yang berkaitan dengan lingkungan pribadinya atau disekitar lingkungan tempat peserta didik melakukan proses pembelajaran.

Sagala (2010:87) menyatakan, "Contextual Teaching and Learning merupakan konsep belajar yang membantu guru mengaitkan antara materi yang diajarkannya dengan situasi dunia nyata siswa dan mendorong siswa membuat hubungan antara pengetahuan yang dimilikinya dengan penerapannhya dalam kehidupan mereka sebagai anggota keluarga dan masyarakat". Menurut Zulaiha (2016) CTL adalah suatu konsep belajar di mana guru menghadirkan situasi dunia nyata dalam kelas dan mendorong siswa membuat hubungan antara pengetahuan yang dimiliki dengan penerapannya dalam kehidupan, sementara siswa memperoleh pengetahuan sedikit demi sedikit, dan dari proses mengkonstruksi sendiri, sebagai bekal memecahkan masalah dalam kehidupannya.

Dengan menerapkan model pembelajaranContextual Teaching and Learning akan memberikan kesempatan kepada siswa untuk bebas berpendapat dan bisa selalu berinteraksi dngan lingkungan, karena proses pembelajaran berpusat pada siswa sehingga siswa bisa aktif dan kreatif dalam mengikuti pembelajaran.

Penelitian ini juga didukung oleh penelitian yang dilakukan oleh Rahmadi (2017) yang dalam hasil penelitiannya menunjukan bahwa sebagian besar skor hasil belajar IPA pada siswa yang dibelajarkan dengan model pembelajaran konvensional cenderung lenih rendah di bandingkan dengan skor hasil belajar IPA siswa yang dibelajarkan dengan model pembelajaran Contextual Teaching and Learning.

Berdasarkan pemaparan di atas, maka dilakukan penelitian tentang Pengaruh Pendekatan Contextual Teaching and Learning Terhadap Hasil Belajar IPA Siswa Kelas V SD Gugus III Kecamatan Busungbiu Tahun Pelajaran 2018/2019.

\section{Metode}

Rancangan penelitian yang digunakan adalah non equivalent post-test only control group design. Populasi dalam penelitian ini adalah seluruh siswa kelas V SD Gugus III Kecamatan Busungbiu sebanyak 70 orang. Sebaran populasi dapat dilihat pada Tabel 2 
Tabel 2. Data Siswa Kelas V SD Gugus III Kecamatan Busungbiu

\begin{tabular}{|c|c|c|}
\hline Sekolah & Kelas & Jumlah \\
\hline SDN 1 Pelapuan & IV & 18 \\
\hline SDN 2 Pelapuan & IV & 13 \\
\hline SDN 1 Umejero & IV & 20 \\
\hline SDN 3 Umejero & IV & 19 \\
\hline \multicolumn{2}{|c|}{ Jumlah } & 70 \\
\hline
\end{tabular}

Dalam penelitian ini, sampel ditentukan dengan menggunakan group random sampling. Sebelum menetapkan sampel penelitian terlebih dahulu dilakuan uji kesetaraan pada masing-masing kelas. Hasil uji kesetaraan diperoleh hasil bahwa seluruh kelas V SDN di Gugus Kakak Tua Kecamatan Nusa Penida memiliki kemampuan yang setara. Untuk menentukan kelas eksperimen dan control, peneliti melakukan system undian. Hasil undian tersebut siswa kelas SDN 1 Pelapuan dipilih sebagai kelas eksperimen dan kelas SDN 3 Umejero sebagai kelas control.

Data pada penelitian ini dikumpulkan dengan beberapa metode pengumpulan data yang disesuaikan dengan permasalahan yang dikaji pada penelitian ini. Sesuai dengan permasalahannya maka data yang diperlukan, yaitu hasil belajar IPA. penelitian ini data hasil belajar IPA diperoleh melalui tes objektif.

Hasil penelitian ini dianalisis bertahap yaitu: analisis deskriptif dan inferensial. Uji prasyarat yang dilakukan adalah uji normalitas sebaran data dan uji homogenitas varians. Uji normalitas dilakukan untuk meyakinkan bahwa sampel berasar dari populasi yang berdistribusi normal, sehingga uji hipotesis dapat dilakukan. Uji normalitas data dilakukan pada dua kelompok data yaitu: 1) hasil belajar IPA eksperimen dan 2) hasil Belajar IPA kelompok control.

Uji homogenitas dimagsud untuk memperlihatkan bahwa dua atau lebih kelompok data sampel berasal dari populasi yang memiliki varian yang sama, setelah dilakukan uji keduanya dilanjutkan dengan uji hipotesis menggunakan uji $\mathrm{t}$ (t-test) dengan rumus polled varians.

\section{Hasil dan Pembahasan}

Data penelitian ini adalah skor hasil belajar IPA siswa sebagai akibat dari pengaruh model pembelajaran Contextual Teaching and Learning pada kelompok eksperimen dengan siswa yang tidak diberikan perlakuan model konvensional pembelajaran pada kelompok kontrol. Rekapitulasi perhitungan data hasil penelitian tentang hasil belajar IPA siswa dapat dilihat pada Tabel 3 berikut

Tabel 3. Nilai Rata-rata Hasil Belajar IPA Kelompok Belajar

\begin{tabular}{ccc}
\hline Hasil Analisis & Kelompok Eksperimen & Kelompok Kontrol \\
\hline Mean & 19,39 & 15,74 \\
Median & 19,8 & 15,3 \\
Modus & 20,5 & 14,5 \\
Varians & 6,95 & 6,87 \\
Standar Deviasi & 2,63 & 2,62 \\
\hline
\end{tabular}

Berdasarkan Tabel 3 nilai rata-rata hasil belajar IPA kelompok siswa yang dibelajarkan dengan menggunakan model pembelajaran Contextual Teaching and Learning sebesar 19,39 dengan varians = 6,95 dan standar deviasi $=2,63$. Sedangkan nilai rata-rata hasil belajar IPA kelompok siswa yang tidak dibelajarkan dengan menggunakan model pembelajaran konvesional sebesar 15,74 dengan varians $=6,87$ dan standar deviasi $=2,62$. Dari data tersebut, menunjukkan bahwa kelompok siswa yang dibelajarkan dengan menggunakan model pembelajaran kooperatif tipe Numbered Head Together memiliki nilai rata-rata hasil belajar yang lebih tinggi dibandingkan kelompok siswa yang tidak dibelajarkan dengan menggunakan model pembelajaran Contextual Teaching and Learning .

Uji normalitas dilakukan untuk menentukan dan membuktikan bahwa frekuensi data hasil penelitian benar-benar berdistribusi normal. Uji normalitas dilakukan terhadap data hasil belajar IPA kelompok eksperimen dan kelompok kontrol. Normalitas sebaran data diuji dengan menggunakan rumus Chi-Kuadrat $\left(X^{2}\right)$ dengan kriteria pengujian data berdistribusi normal jika $X^{2}$ hitung $<X^{2}$ tabel pada taraf signifikansi $5 \%$ dengan $\mathrm{dk}=$ jumlah baris -1 . Berdasarkan analisis data yang dilakukan, dapat disajikan rangkuman hasil uji normalitas sebaran data hasil belajar IPA kelompok eksperimen dan kontrol pada 
Tabel 4.

Tabel 4. Hasil Uji Normalitas Sebaran Data

\begin{tabular}{ccccc}
\hline No & Kelompok Data & $\mathbf{X}^{2}$ hitung & $\begin{array}{c}\text { Nilai Kritis dengan Taraf } \\
\text { Signifikansi 5\% }\end{array}$ & Status \\
\hline 1 & Post-test Eksperimen & 0,374 & 5,591 & Normal \\
2 & Post-test Kontrol & 1,466 & 5,591 & Normal \\
\hline
\end{tabular}

Kaidah uji normalitas sebaran data adalah jika hit < tabel maka data berdistribusi normal, sedangkan jika hit > tabel maka data tidak berdistribusi normal. Berdasarkan hasil perhitungan uji normalitas post-test kelompok eksperimen, diperoleh hit $=0,374$ dan tabel $=5,591$ pada taraf signifikansi $5 \%$ dan $\mathrm{db}=5-2-1=2$. Ini berarti bahwa hit $<$ tabel, maka data hasil post-test kelompok eksperimen berdistribusi normal. Sedangkan hasil perhitungan uji normalitas post-test kelompok kontrol, diperoleh hit $=1,466$ dan tabel $=5,591$ pada taraf signifikansi $5 \%$ dan $d b=5-2-1=2$. Ini berarti bahwa hit $<$ tabel, maka data hasil post-test kelompok kontrol berdistribusi normal.

Setelah diketahui bahwa seluruh sebaran data berdistribusi normal, maka dilanjutkan dengan uji homogenitas varian. Uji homogenitas dilakukan terhadap varians pasangan antar kelompok eksperimen dan kontrol. Uji yang digunakan adalah uji-F dengan kriteria data homogen jika $F_{\text {hitung }}<\mathrm{F}_{\text {tabel. }}$. Ringkasan hasil uji homogenitas varians antar kelompok eksperimen dan kontrol disajikan pada Tabel 5.

Tabel 5. Ringkasan Hasil Uji Homogenitas

\begin{tabular}{lccc}
\hline \multicolumn{1}{c}{ Kelompok Data Hasil Belajar } & $\mathbf{F}_{\text {hitung }}$ & $\mathbf{F}_{\text {tabel }}$ & Status \\
\hline $\begin{array}{l}\text { Eksperimen } \\
\text { Kontrol }\end{array}$ & 1,01 & 2,25 & Homogen \\
\hline
\end{tabular}

Berdasarkan Tabel 5, diketahui Fhitung hasil belajar IPA siswa kelompok eksperimen dan kontrol adalah 1,01. Sedangkan Ftabel dengan dbpembilang $=17$, dbpenyebut $=18$, dan taraf signifikansi $5 \%$ adalah 2,25. Hal ini berarti Fhitung < Ftabel sehingga varians data hasil belajar IPA siswa kelompok eksperimen dan kontrol adalah homogen.

Setelah diperoleh hasil dari uji prasyarat analisis data, dilanjutkan dengan pengujian hipotesis penelitian. Pengujian hipotesis tersebut dilakukan dengan menggunakan uji-t sampel independent (tidak berkorelasi) dengan rumus polled varians dengan kriteria $\mathrm{H}_{0}$ tolak jika $t_{\text {hitung }}>\mathrm{t}_{\text {tabel }}$ dan $\mathrm{H}_{0}$ terima jika $\mathrm{t}_{\text {hitung }}$ $<t_{\text {tabel. }}$ Ringkasan uji hipotesis disajikan pada Tabel 6.

Berdasarkan analisis data menggunakan uji-t yang ditunjukkan pada diketahui thitung $=5,28$ dan ttabel $(\mathrm{db}=35$ dan taraf signifikansi 5\%) = 2,042. Hasil perhitungan tersebut menunjukkan bahwa thitung lebih besar dari ttabel (thitung > ttabel) sehingga hasil penelitian adalah signifikan. Hal ini berarti, terdapat perbedaan yang signifikan hasil belajar IPA antara kelompok siswa yang dibelajarkan dengan model pembelajaran model pembelajaran Contextual Teaching and Learning dan kelompok siswa yang dibelajarkan dengan model pembelajaran konvensional pada siswa kelas V SD Gugus III Kecamatan Busungbiu Tahun Pembelajaran 2018/2019. Adanya perbedaan yang signifikan disebabkan karena perbedaan perlakuan pada langkah-langkah pembelajaran dan proses penyampaian materi. Pembelajaran dengan model pembelajaran Contextual Teaching and Learning lebih mengutamakan usaha siswa untuk memperoleh informasi mengenai materi pembelajaran melalui diskusi dengan temannya dalam kerjasama kelompok.

Pada pertama mengarahkan pada kontruktivisme, Guru melibatkan siswa untuk berpikir dan mengkontruksi pengetahuannya, dimana guru mengaitkan materi pembelajaran dengan konteks masalah sehari-hari mengenai pecahan sebagai perbandingan dan skala yang terdapat di lingkungan siswa.Siswa dapat menemukan hubungan antara ide-ide baru dan hal-hal yang sudah diketahui siswa melalui pertanyaan yang diajukan

Tahap kedua menciptakan pembelajaran yang inquiryMasing-masing siswa menyelesaikan masalah yang diberikan secara individu secara inquiry, dimana di dalamnya terdapat proses pengamatan dari materi yang diberikan guru sebelumnya, bertanya kepada guru mengenai kesulitan yang dihadapi, mengajukan dugaan sementara dengan menuliskan secara urut langkah-langkah pemecahan masalah, pengumpulan data dengan menuliskan cara pengerjaan sesuai dengan rumus, dan yang terakhir adalah membuat kesimpulan jawaban. 
Tahap ketiga Mengarahkan pada pengajuan pertanyaan yang dilakukan oleh siswa, Guru mengajukan pertanyaan kepada siswa untuk menggali sejauh mana pengetahuan siswa mengenai topik pembelajaran, serta untuk mengembangkan sifat ingin tahu siswa.Guru bertanya jawab mengenai pengertianperbandingan dan skala, kegunaan perhitungan perbandingan dan skala, serta masalah yang berkaitan dengan perbandingan dan skala dalam kehidupan sehari-hari.

Tahap empat mengorganisasi siswa dalam kelompok masyarakat belajan, Guru membentuk siswa menjadi beberapa kelompok agar terjadi proses masyarakat belajar yang dapat bekerjasama dalam menyelesaikan tugas. Guru membagi kelas menjadi beberapa kelompok yang terdiri dari 4-5 anak dalam tiap kelompok. Guru menyampaikan tugas dan peran masing- masing anggota dalam setiap kelompok.

Tahap lima guru menghadirkan model dalam pembelajaran, Guru menghadirkan model berupa alat peraga maupun contoh melakukan sesuatu dalam proses pembelajaran agar siswa lebih paham mengenai materi yang diajarkan. Tahap enam Guru melakukan refleksi melalui tanya jawab dengan siswa mengenai proses pembelajaran. Tahap terakhir Guru melakukan penilaian autentik baik untuk proses pembelajaran maupun hasil belajar.

Berdasarkan pemaparan kegiatan model pembelajaran Contextual Teaching and Learning di atas menunjukan bahwa suasana belajar terasa lebih efektif, kerjasama dalam kelompok dalam pembelajaran ini dapat membangkitkan semangat siswa untuk memiliki keberanian dalam mengemukakan pendapat dan berbagai informasi dengan teman lainnya dalam membahas materi pelajaran (Trianto:2009). .

Perbedaan cara pembelajaran antara pembelajaran dengan model pembelajaran Contextual Teaching and Learning dengan kelompok siswa yang dibelajarkan model pembelajaran konvensional. tentunya akan memberikan dampak yang berbeda pula terhadap hasil belajar siswa. Pembelajaran dengan model pembelajaran Contextual Teaching and Learning memungkinkan siswa untuk belajar secara aktif dan bermakna karena pengetahuan dibangun sendiri oleh siswa karena siswa mampu menemukan sendiri konsep-konsep yang dipelajari tanpa harus selalu tergantung pada guru, mampu memecahkan masalah-masalah yang berkaitan dengan konsep yang dipelajari, bekerja sama dengan siswa lain, dan berani untuk mengemukakan pendapat maka pengetahuan yang diperoleh akan lebih lama diingat oleh siswa. Dengan demikian, hasil belajar IPA siswa yang dibelajarkan dengan model pembelajaran Contextual Teaching and Learning. akan lebih baik dibandingkan dengan siswa yang dibelajarkan dengan model pembelajaran konvensional.

Hasil penelitian ini juga diperkuat oleh penelitian yang dilakukan oleh Muliani (2013) hasil penelitiannya menunjukkan bahwa ada pengaruh pendekatan Contextual Teaching and Learning (CTL) berbantuan media gambar seri terhadap keterampilan menulis deskripsi bahasa Indonesia.

Begitu juga penelitian eksperimen yang dilakukan Rahmadi (2017) hasil penelitiannya menunjukkan bahwa model pembelajaran Kontektual berbantuan media konkret berpengaruh terhadap hasil belajar IPA siswa kelas V SD di Gugus V Kecamatan Petang Tahun Pelajaran 2017/2018. Hal ini membuktikan bahwa model pembelajaran Contextual Teaching and Learning berbantuan media konkret berpengaruh secara signifikan terhadap kompetensi pengetahuan IPA.

Selain itu, penelitian serupa juga pernah dilakukan oleh Nuridwani, dkk (2015) peningkatan kemampuan penalaran matematis siswa yang memperoleh pembelajaran dengan pendekatan CTL lebih baik dari siswa yang memperoleh pembelajaran dengan pendekatan konvensional, dan 2) peningkatan kemandirian belajar siswa yang memperoleh pembelajaran dengan pendekatan CTL lebih baik dari siswa yang memperoleh pembelajaran dengan pendekatan konvensional..

Berdasarkan paparan di atas, maka dapat disimpulkan bahwa terdapat pengaruh model pembelajaran Contextual Teaching and Learning terhadap hasil belajar IPA siswa Kelas V SD Gugus III Kecamatan Busungbiu Tahun Pembelajaran 2018/2019

\section{Simpulan dan Saran}

Berdasarkan hasil pengujian hipotesis dan pembahasan, maka temuan dalam penelitian ini menyatakan bahwa terdapat pengaruh model pembelajaran Contextual Teaching and Learning terhadap hasil belajar IPA. Hasil analisis menunjukan bahwa $t_{\text {hitung }}$ adalah 5,28 sedangkan nilai $t_{\text {tabel }}$ dengan taraf signifikan 5\% adalah 2,042. Rata-rata hasil belajar IPA kelompok yang menggunakan terdapat pengaruh model pembelajaran Contextual Teaching and Learning adalah 19,39 termasuk kategori tinggi dan ratarata pemahaman kelompok siswa yang menggunakan model pembelajaran konvensional 15,74 termasuk kategori sedang. Hal ini berati, rata-rata hasil belajar IPA kelompok siswa yang mengikuti terdapat pengaruh model pembelajaran Contextual Teaching and Learning lebih besar daripada rata-rata hasil belajar IPA kelompok siswa yang menggunakan model pembelajaran konvensional. 


\section{Daftar Rujukan}

Handini, Dea, Diah Gusrayani, Regina Lichteria Panjaitan. 2016. Penerapan Model Contextual Teaching and Learning Meningkatkan Hasil Belajar Siswa Kelas IV pada Materi Gaya. Jurnal Pena Ilmiah: Vol. 1, No. 1 Hal. 451-560. Tersedia Pada: http://ejournal.upi.edu/index.php/penailmiah/article/view/2974.

Kasmawati, Nur Khalisah Latuconsina, Andi Ika Prasati Abrar. 2017. Pengaruh Model Pembelajaran Contextual Teaching And Learning (CTL) terhadap Hasil Belajar. Jurnal Pendidikan Fisika Vol. 5 No. 2 Hal. 70-75. Tersedia Pada: http://journal.uin-alauddin.ac.id/indeks.php/PendidikanFisika.

Lasmawan, Wayan. 2004. Pengembangan model pembelajaran IPS Sekolah Dasar dengan Menggunakan Model STM (Studi Pembelajaran pada Siswa Kelas V Sekolah Dasar di Kabupaten Buleleng - Bali). (Disertasi). Bandung: PPS UPI Bandung.

Oemar Hamalik. 2012. Manajemen Pengembangan Kurikulum.. Bandung: Remaja Rosdakarya,

Rahmadi, I. W. H, Parmiti, P. D, \& Widiana, I. W. 2017. Pengaruh Model Pembelajaran Kontekstual Berbantuan Media Konkret Terhadap Hasil Belajar IPA Siswa Kelas V SD Di Gugus IV Kecamatan Petang Tahun Pelajaran 2017/2018. Mimbar PGSD, 6(1).

Susanto, Ahmad. 2013. Teori Belajar dan Pembelajaran di Sekolah Dasar. Jakarta: Kencana.

Sagala, Syaiful. 2003. Konsep dan Makna Pembelajaran. Bandung: Alfabeta.

Sulthon. 2016. Pembelajaran IPA yang Efektif dan Menyenangkan Bagi Siswa Madrasah Ibtidaiyah (MI). Elementary Vol. $4 \quad \int$ No. 1 Hal. 38-54. Tersedia Pada: http://journal.stainkudus.ac.id/index.php/elementary/article/download/1969/pdf.

Sumiyadi, Kasmadi Imam Supardi, Masturi. 2015. Pengembangan Perangkat Pembelajaran Ipa Berbasis Inkuiri Dan Berwawasan Konservasi. Journal of Innovative Science Education Vl. 4 No. 1 Hal. 1-8. Tersedia Pada: http://journal.unnes.ac.id/sju/index.php/jise.

Suriyani, Henny Irma, Murni Sabilu, Safilu. 2017. Pengaruh Pembelajaran Terpadu Tipe Connected Menggunakan Pendekatan Scientific Terhadap Keterampilan Berpikir Kritis Siswa Pada Materi Sistem Pencernaan Manusia Di Kelas VIII SMP Negeri 10 Kendari. J. A M P I B I 2 (1) hal. $(75$ - 83). Tersedia Pada: http://ojs.uho.ac.id/index.php/ampibi/article/download/5060/3781.

Zulaiha, Siti. 2016. Pendekatan Contextual Teaching And Learning (CTL) Dan Implementasinya Dalam Rencana Pembelajaran PAI MI. Jurnal Pendidikan Islam vol. 1, no 01, Hal. 41-60. Tersedia Pada: http://journal.staincurup.ac.id/index.php/belajea/article/view/84. 